\title{
The Holy Land of Matrimony: The Complex Legacy of the Broomstick Wedding in American History
}

\author{
Tyler D. Parry
}

The 1976 publication of Alex Haley's Roots: The Saga of an American Family forced Americans to reckon with the experiences of black people in the United States. Haley's novel was a historical fiction depicting his ancestral history, beginning with his eighteenth-century West African forebears and concluding in the late twentieth century. Roots vividly illuminated the African experience in America and unveiled a distinct narrative that drifted away from the traditional Anglo-American histories. Haley personified this experience through his initial protagonist, Kunta Kinte, a character who both physically and psychologically attempts to resist the system that forcibly took him from his homeland and placed him in chains. Despite Kunta's fortitude in refusing to denounce his Muslim Mandinka heritage, he begrudgingly engages cultural traditions associated with enslaved Americans, including the popular wedding tradition "jumping the broom." Initially, this ritual "seemed ridiculous to Kunta for such a solemn occasion," but he reluctantly joins his American-born bride Bell in a wedding ceremony conducted in the slave quarters. ${ }^{1}$ Following the blessing bestowed upon them by an elderly slave named "Aunt Sukey," they jumped the broomstick "into de holy lan' of matrimony" surrounded by festive slaves and an approving master. ${ }^{2}$ Though he held reservations, Kunta's participation in the ritual signified his gradual transition from "African" to "African American" cultural identity. 
Whereas Kunta apprehensively embraced slave marital rites, his grandson "Chicken George" willingly performed the custom at his own wedding in the nineteenth century. This suggests that the broomstick tradition continued across generations of servitude and became an integral component of slave wedding traditions. ${ }^{3}$ Serving as symbols for African American readers, the genealogical connection between Kunta Kinte and Chicken George was critical for black Americans seeking cultural links to their own enslaved ancestors, compelling them to grapple with a history many felt was otherwise hidden from them. Haley's depiction of slaves' cultural resilience encouraged his audience to consider how slavery molded the unique cultural developments of black America. Inspired by Roots' vivid description, the ceremony became a focal point in defining African American heritage among readers and viewers of the televised miniseries. Haley essentially reintroduced the popular slave custom to the descendant community and provided a blueprint for those seeking to perform it in the twentieth century. Consequently, many African Americans embraced the "heritage wedding" concept, in which traditional Christian ceremonies included Afrocentric elements for those seeking to pay homage to their ancestors in Africa and America. The ceremony dignified their ancestors' struggles to marry under a system that disrespected their familial ties. Similar to the slave wedding in Roots, couples leaped over a broom after the ministerial blessings and the final salutation of the bride and groom, ultimately "jumping" into domestic life surrounded by witnesses.

The broomstick ritual's sudden popularization in the late twentieth century prompts some compelling questions: why did it take over a century for African Americans to re-embrace a custom that many believed was universally practiced by their ancestors? Why did the practice fall out of use after the Civil War? Where does the ritual originate? Past scholarship typically portrays Haley's work as a pivot point in African American cultural development, pointing to the increased inclusion of jumping the broomstick as an appendage to modern wedding ceremonies after Roots ' release. ${ }^{4}$ Indeed, including this enigmatic custom appears more than coincidental, but past scholarship failed to consider the transcultural connotations of the broomstick wedding in the century between slavery's demise in 1865 and Roots' popularity in the mid-1970s. Despite its cross-racial, multicultural roots, the broomstick wedding's post-Roots revival reoriented how Americans envisioned its position in American history. Many assume the custom is unique to the black community and its cultural ownership is exclusive to African Americans. These authors generally overlook that Americans of various racial backgrounds utilized broomstick traditions that survived in modified form throughout the nineteenth century and into the twentieth. ${ }^{5}$ By tracing the broomstick wedding's appeal to both black and white Americans, this article shows how it exemplifies the problem of cultural authenticity as a category of social analysis. I argue that while jumping the broom was a documented wedding tradition in both black and white communities in the nineteenth century, events such as the aftermath of the American Civil War, the rise of Black 
Power, and the greater scholarly attention to US slavery adjusted the "collective memory" of the ritual in American history. ${ }^{6}$ Whereas one's inclination to "jump the broom" in the nineteenth century was largely based upon one's geographical and social class position, its public conception in the late twentieth century shifted to racial identity when prominent African American authors contended the ritual stemmed from African traditions. In analyzing nearly two centuries of divergent folk histories that reference the custom, this article reveals how this ethnically diverse tradition evolved into a practice largely and, it seems, sometimes exclusively associated with African Americans.

Analyzing the broomstick wedding's original representations in the nineteenth century and its resurgence as a symbol of African American heritage in the post-Civil Rights era fills two historiographical gaps. First, past works dealing with American slavery have largely neglected to consider the multicultural dimensions of the broomstick ceremony, primarily limiting their analyses to a few brief references concerning its place in slave wedding traditions. ${ }^{7}$ Secondly, it revises the popular contention that Roots was solely responsible for reviving the broomstick wedding in American popular culture. ${ }^{8}$ While Haley's work was crucial in expanding the custom's influence in African American cultural practices, I argue he was informed by a number of pivotal cultural movements that preceded his publications. Indeed, the popularization of rural traditions in the literature of the early to mid-twentieth century, alongside scholarship that paid greater attention to slave culture in the 1960s and 1970s, provided a basis for reframing America's historical connection with the broomstick tradition prior to Roots' emergence in American literature and film. As Haley was a student of slavery, the South, and the African American experience, his portrayal of Southern slave societies ultimately grew out of these cultural and intellectual precedents. Roots must be understood as a product of these societal changes, rather than simply a piece of unprecedented historical fiction.

Due to its ubiquitous resurgence throughout the United States in the late twentieth century, scholars and cultural critics usually examine the broomstick wedding through a specific sociopolitical lens or historiographical movement. Some historians claim it was the primary form of slave marriage throughout the South, while others have questioned its significance to the enslaved community. ${ }^{9}$ Historians Shane and Graham White, for instance, argued that previous historians exaggerated the broomstick wedding's prominence in slave nuptials. ${ }^{10}$ John Blassingame contended that jumping the broom was simply a "postnuptial revelry" largely misremembered by ex-slaves interviewed in the 1930s. ${ }^{11}$ Blassingame asserted that historians who believed that the broomstick wedding comprised the entirety of the slave wedding ceremony were largely "misled about the character of wedding ceremonies in the quarters" because they did not fully "examine what the slaves told" their interviewers. ${ }^{12}$ Both assertions were important in challenging scholars to think more critically about the cultural development of African American marital rites, but their conclusions were limited by the assumption that jumping the broom was confined to 
the African American experience. This limited scope accepts that jumping the broom was a ritual devoid of meaningful history, causing many cultural historians to downplay its significance to the enslaved and their descendants. If the broomstick ritual transcended racial and national boundaries, however, and was practiced by other communities, one can use this larger source base to more fully articulate how slaves and their contemporaries conceptualized the ritual's importance to their group development.

A few scholars have placed the ritual beyond the parochial boundaries of the American nation state and the enslaved community, but confusion over the broomstick wedding's cultural origins made their conclusions largely speculative. In his magnum opus, The Black Family in Slavery and Freedom, Herbert Gutman found that white communities also practiced this form of matrimony, though he admitted its meaning remained "obscure" due to the brevity of exslaves' descriptions. ${ }^{13}$ Arguing for slave agency, Gutman imaginatively connected the broomstick wedding to the cosmological underpinnings of slave religion and folklore, contending that jumping the broom "(whatever its origins) was related closely to Afro-American magical and religious beliefs." ${ }^{14}$ Despite this creative proposition, Gutman's analysis did little to satisfy scholarly consensus. Subsequent analyses typically referenced the custom, but extended very little attention to uncovering its meanings beyond simple folk ceremony. ${ }^{15}$ Thus, the broomstick wedding is simultaneously envisioned as a quaint, or "fun," gesture that followed the ceremony, an act of resistance, or a formality that was "forced" upon slaves by their masters. ${ }^{16}$ Since slaves' marriages accorded no legal recognition, this relatively obscure wedding custom is represented differently based upon an author's political or sociocultural motivations.

Jumping the broomstick has certainly engrossed scholastic and popular imaginations, but the historiography holds no sustained analysis of the ritual's place within the transition from "slave marriage" in the antebellum period to "legal marriage" in the postbellum era. ${ }^{17}$ Many works reference its existence in slavery, but none have satisfactorily considered its continuation after 1865 . To answer this query I interrogate the broomstick ritual in three distinct periods of its existence, revealing how various societies remain committed to its cultural value in their marriage rites. First, I scrutinize how white and black communities in the United States and Britain utilized the custom in their own locales, articulating how the ritual appealed to many oppressed groups on both sides of the Atlantic. Next, I examine how the end of slavery in the United States caused African Americans' to downplay the physical enactment of jumping the broom, though evidence suggests that some rural communities, both black and white, remained committed to its symbolic importance in the early twentieth century. Lastly, I analyze how the ceremony was reimagined following the release of Alex Haley's immensely popular novel Roots: The Saga of an American Family and how this conceptual shift explains the custom's contested position in the American cultural experience. 
As property, slaves were unable to contract legally sanctioned marriages, negating the need for the state or federal government to recognize the union. One 1857 publication, The Autobiography of a Female Slave, disclosed that the legal invalidation of slave matrimony encouraged some slave owners to forego "the tomfoolery of a preacher" since "the law did not recognize the validity of negro marriage." ${ }^{18}$ Ideally, one might imagine that a folk ritual like jumping the broomstick would provide ceremonial endorsement to a marital celebration outwardly stripped of sacred connotations. This was certainly the case for many enslaved African Americans, but a comprehensive reading of marriages described by former slaves interviewed by employees of the Works Progress Administration (WPA) during the 1930s reveals the situation was more complex. The ceremonies range from descriptions of the broomstick wedding to those who witnessed a "big wedding" that included a "new white dress . . . the white folks church ... [and] a lot of good eatings." In contrast, Fannie Hughes's claimed that despite having a "colored preacher ... they wasn't no big weddin's," and Sallie Blakely of Georgia contended "there was no formal marriage ceremony in those days." 19 The WPA testimonies ultimately reveal that slaves married in various formats, and the broomstick wedding comprised one of many.

The WPA narratives remain the subject of a perpetual controversy regarding their reliability as historical sources, as scholars have questioned whether the memories of individuals nearly seven decades removed from slavery can be trusted. ${ }^{20}$ This scrutiny has caused some authors to dismiss practices like jumping the broom as folkloric developments created by an elderly generation of African Americans too far removed from the experience of enslavement, as they were freed at a young age following the Union's victory in the Civil War. ${ }^{21}$ However, if the WPA references to jumping the broom can be corroborated by contemporary sources from both white and black southerners in the nineteenth and twentieth centuries, then it would strongly suggest that African Americans' recollections of the same custom seven decades after slavery ended were based upon more than invalidated folklore. ${ }^{22}$ Indeed, slaves from states as far separated geographically as North Carolina and Louisiana revealed very similar accounts of broomstick weddings in the antebellum period, as well as the degree to which some of them continued to jump the broom as they entered the postbellum period. Former slaves' descriptions of the broomstick ceremony are also verified by testimonies from contemporaneous white communities both inside the United States and abroad. ${ }^{23}$ In essence, these testimonials are important resources for ascertaining how jumping the broom figures into the intersecting operations of history and memory in the development of American popular culture.

In order to more fully understand slaves' folk marriages we must scrutinize these practices from broader perspectives and interrogate the findings of previous scholarship. ${ }^{24}$ Some authors attempted to place the ritual in an African context, arguing that residual influences of broomstick traditions throughout Africa were modified in North American slave communities. ${ }^{25}$ The problem with this 
interpretation is that no broomstick rituals in western Africa bear any resemblance to the slave wedding. ${ }^{26}$ The clearest link to the American broomstick ceremony is actually found in the British Isles among isolated and ostracized communities of Celtic and Gypsy descent, as well as among rural Anglo-Saxons. Oral traditions from a community in Northern Wales reveal that their ancestors married by placing a broomstick at the threshold of the doorstep where they were designed to live, and "the young man jumped over it first into the house, and afterwards the young woman in the same way . . . by jumping over backwards over the besom [broom] the marriage was broken.. ${ }^{27}$ The rural setting of this Welsh community likely kept the tradition alive throughout the nineteenth century, and as with many folk groups, it was the community's recognition of the marriage that ultimately sanctioned the union. The broomstick ritual became ubiquitous throughout Britain, though popular works often portrayed it as a ritual reserved for ethnic pariahs and other marginal groups. In one example, an eighteenth-century British caricature called the "Scotch Wedding" depicted a noble couple jumping over a broomstick in their bedroom to the tune of an elderly woman playing bagpipes. Seeking to demoralize Scottish culture, the caricature used the broomstick wedding as an idiom to rehearse the idea of a morally superior Anglo society against the practices of Scottish Celts. ${ }^{28}$

British Gypsies (Roma) also engaged various forms of broom jumping. ${ }^{29}$ First appearing in records of the seventeenth century, this nomadic group faced severe legislation that curtailed their transient lifestyle. The broomstick ceremony met the challenge of providing matrimonial formality to partners who frequently traveled throughout the British countryside. In one account, the groom obtained "two branches of broom" procured by his daughter, threw the branches at his bride's feet, and "took her by the hand and together they leapt over them. Thus they were married in this fashion. ${ }^{\prime 30}$ Another observer documented a similar wedding custom in the nineteenth century. Under the direction of an elder, the wedding guests lined up into two rows, and the groom and bride walked between them and jumped a broomstick held at the end of the human tunnel. ${ }^{31}$ Gypsy accounts reveal that the ritual could be modified and altered depending upon the practitioner's preference. The custom's various expressions in the British Isles reveal its multicultural appeal, especially for communities ostracized from elite cultural practices. As the ritual was carried across the Atlantic it was similarly modified by various groups, all of whom shared a common experience of isolation and expulsion from elite society.

The broomstick wedding's popularity among multiple American ethnic and racial communities suggests that "southern culture" was developed through the cultural exchanges that occurred during the transatlantic era, in which Europeans and Africans crisscrossed the Atlantic and arrived at numerous colonial destinations intertwined by trade and production. ${ }^{32}$ While wealthy white American men controlled the arenas of politics, legislation, and other venues of social capital, cultural dominance was never absolute for either oppressors or subjects, and various traditions were appropriated and reimagined to meet 
a particular community's needs. At an unknown moment in time, broomstick ceremonies arrived in North America, and the United States would become the only country outside the British Isles with an extensively documented tradition of this marriage rite. The primary difference between the two locations, of course, concerns the practitioners of the ritual.

The most substantial evidence comes from rural communities who lived in the US South during the antebellum period. ${ }^{33}$ The broomstick ceremony provided these populations an opportunity to hold a marital ceremony under the adverse conditions of the southern frontier. For slaves, the ceremony served practical purposes due to the precarious conditions of chattel slavery. If the master provided no endorsement to the ceremony, or a preacher was unavailable to oversee the service, a broomstick was usually readily available and used at the discretion of the participants. ${ }^{34}$ For Appalachian whites the ceremony afforded an opportunity to legitimize the union in the absence of a minister, a circumstance largely due to their geographical isolation. In the traditions of Louisiana Cajuns, the ceremony was used for similar purposes, though at times it also symbolized their resistance against the encroachments of churchmen who did not approve their marital engagements. These various groups used oral traditions to infuse the ritual with meanings most useful to their community's needs. The notion that these groups all embraced a similar wedding ritual suggests that the US South was culturally more homogenous than commonly portrayed. Indeed, each group suffered under the region's racist and class-stratified slave society, though each situation was unique.

Since the African ancestors of the enslaved held no cultural attachments to the custom, one might wonder why it penetrated American slave culture so successfully. As opposed to subjects like culinary fusion, dancing, or singing among the enslaved, all of which blended African precedents with New World circumstances, an unfamiliar European folk custom initially appears to have little practical value for a group barred from embracing legally protected marriages. Since we are dealing with folklore and oral history, it is difficult to pinpoint their initial reasons for accepting the ritual into their own communities. The master's persuasion is certainly one way in which the ritual was transmitted, as slave owners were present at the ceremony in about forty percent of the WPA accounts. ${ }^{35}$ At times masters would hold the broom, as revealed in Chaney Mack's narrative: 'Masta would say, 'Now git ready to Jump de Broom.' De Old Masta would hold de broom. Dey would hold hands and Jump dis way and den back again." ${ }^{36}$ In other scenarios masters encouraged and observed the ritual, as in ex-slave Callie Elder's testimony where "Marse Billy made 'em go up to de hall of de big house and jump backwards over a broom." 37 Some historians have interpreted the master's presence and their use of "coercive" language as a tactic to impose the custom upon the slaves. ${ }^{38}$ However, recent scholarship contends that only a minority of the ex-slaves who remembered observing or participating in the ritual recalled any coercive language used during the ceremony. ${ }^{39}$ Ultimately, if a slave owner desired to maintain order and pro- 
ductivity it was impractical to force slaves to embrace a specific marriage ritual, especially if it was deemed a trivial formality. Masters were more interested in their slaves' abilities to reproduce, and, with certain exceptions to favored servants, largely left the details of the wedding ceremony to the enslaved couple. ${ }^{40}$

Slave owners were likely familiar with the custom's origins across the Atlantic and held some responsibility in familiarizing slaves with the ritual, but slaves ultimately decided which rituals to adopt into their communities. Outside the master's influence, it is equally as feasible that slaves appropriated jumping the broom from communities that were already practicing it. Previous scholarship has documented connections and cultural exchanges between Celtic immigrants and peoples of African descent in North America, providing evidence that the folk ceremonies of these rural British communities were attractive to African-descended peoples held in bondage. ${ }^{41}$ Similar to their British counterparts, this ceremony was a practical method for slaves to sanction their unions. As it became imbedded within slave traditions, its importance as a symbol of marital commitment became more prevalent. Indeed, a number of slaves initiated the ritual independently of the master, and multiple accounts reveal diverse ritual performances that occurred throughout the South. Stephen Varner, a former Alabama slave, recalled, "slaves did not have a preacher to marry them. The only kind of service that they had was to place a straw broom on the floor and step over it together and then they were married. The slaves would [then] gather around and sing and dance for the bride and groom." ${ }^{42}$ Varner's community could have chosen to forego the ceremony, but their conscientious employment of the broomstick ritual suggests it held some cultural value. The legal invalidity of slave weddings rendered them distinct from other ostracized communities in the United States, but the broomstick wedding held a similar meaning for these disenfranchised groups.

Poor and rural white Americans generally did not document their own histories in the nineteenth century, but contemporary works of fiction and newspapers demonstrate that the custom was familiar to the white population, especially those who lived in frontier societies. In critiquing the lagging legislation of an appropriate marriage, one newspaper bluntly described the ceremony in South Carolina during the mid-nineteenth century: "If Mr. A and Miss B jump over a broom, the former saying I take this woman to be my wedded wife, and the latter I take this man to be my wedded husband, and go to housekeeping they are legally married." ${ }^{33}$ The report suggests that marriage legislation and the overall difficulty of traversing rural terrain prompted couples to participate in folk customs that provided sufficient recognition of a marital commitment. James Fenimore Cooper's 1827 novel The Prairie described "broomstick jumpers" as comparable to populations of non-Christians who supposedly held little concern for formal matrimony. ${ }^{44}$ As novels and newspapers were primary venues for disseminating cultural beliefs to their readers, literate populations became familiar with these folk customs, even if they did not use them. 
Knowledge of the broomstick ritual's multicultural nature even crossed racial boundaries. Ex-slave Willis Cozart testified that while slaves on his own plantation in North Carolina employed the broomstick wedding, he also claimed, "De pore white folks done de same way." 45 For slaves to know that poor whites held similar marriage customs suggests that currents of cultural exchange resonated throughout antebellum Southern society. ${ }^{46}$ The exchange of cultural knowledge, however, also led to the perpetuation of racist stereotypes. In antebellum minstrelsy, whites in blackface depicted jumping the broom as a frivolous ceremony associated with slaves. In one minstrel show tune called "De Nigger's Wedding-Day" white performers sang about an enslaved man "from ole Virginia" who delivers a rhyme scheme that discusses his courtship of "a yallow gal named Dinah" who lived on another plantation. As the clergyman closed the marriage ceremony the couple "jumpe'd ober de broom and wed widout any bodder" after which the man went to "massa's house" and the woman was obliged to tell the news to her "modder." ${ }^{\text {" } 7}$ Usage of the word "nigger" is prevalent throughout the text alongside the employment of broken English that was common in white imitations of black speech. Minstrel shows are relevant for probing cultural dissemination since these performances were often done for northern white audiences personally unfamiliar with slave marital customs. Thus, slaves' speech patterns and their use of the broomstick marriage helped determine their status as "other" in the United States, despite the fact that poor whites held similar proclivities. It is uncertain how these white performers obtained their knowledge of slave culture, but these performances reveal that many antebellum whites understood that the practice was connected to slaves' marriage traditions.

Even when a literal leap over an object did not occur, the phrase "jumping the broomstick" was used as an idiom for white people who married informally. In 1848, the New York Evangelist criticized Kentucky marriage law by arguing that it was "not a bit more binding upon the parties than jumping over the broom-stick." ${ }^{48}$ The performance of broomstick weddings would continue throughout the remainder of the nineteenth century and into the twentieth, though for certain groups the meaning of the ceremony changed. Rural white communities still used the ritual in areas where ministers were either unavailable or disagreeable, but the notion of "jumping the broomstick" became less a literal practice and more a symbol for tradition. Among many folk groups marriages began to take place among justices of the peace or itinerant preachers, and the phrase "jump the broom" was largely used as a colloquial expression synonymous with "getting married." For the formerly enslaved, the custom received mixed reactions after they attained freedom. For African Americans remaining in the rural South, the custom served a similar function as their white counterparts who dwelled in peripheral locations. African Americans, however, were now forced to reckon with the memory of slavery, and many preferred to detach themselves from the experience by performing the orthodox ceremonies of an institution that they were legally denied for over 200 years. 
In May 1865 Congress created under the jurisdiction of the secretary of war the Bureau of Refugees, Freedmen, and Abandoned Lands, which ensured freed slaves in Maryland, Washington D.C., West Virginia, Kentucky, and the eleven Confederate states were able to obtain legally recognized unions. One of the first declarations by the "Freedmen's Bureau" was that "in places where the local statutes make no provisions for the marriage of persons of color, the Assistant Commissioners are authorized to designate officers who shall keep a record of marriages, which may be solemnized by any ordained minister of the gospel." ${ }^{49}$ Many African Americans exercised their freedom by heading to the courthouse or chapel to receive the coveted marriage license. ${ }^{50}$ The government's vigorous emphasis on legal, Christian matrimony prompted folk rituals like jumping the broomstick to fall out of favor with newly freed African Americans who were trying to advance in a society they believed might accord them more opportunity.

The ability to obtain a clergyman through their own volition was surely tempting for many African Americans who were previously unable to choose a minister when they married as slaves upon the plantation. ${ }^{51}$ According to former Louisiana slave Bongy Jackson, the broomstick wedding was the main ceremony on his plantation, but "after the Cibil War, soon's they got a little ole piece of money they got a preacher and had a real weddin'." 52 Rena Raines's narrative was nearly identical to Jackson's, as she revealed that her parents engaged the broomstick wedding as slaves, but came "ter Raleigh [North Carolina] atter de surrender an wus married right." 53 The notion that a postbellum wedding, devoid of slave customs, was considered the "real" or "right" type of ceremony holds important connotations for interpreting the attitudes that helped downplay the memories of slaves' cultural lives in the first half of the twentieth century. In many respects, the involvement of government officials and zealous ministers led many former slaves toward a degree of cultural amnesia, in which the embarrassing components of chattel slavery were either denied or relegated to memories that died with the individual.

Each formerly enslaved respondent remembered and reimagined slavery differently, and at times scholars are left with accounts that appear in conflict. The respondents' collective memories of broomstick weddings are no different. Josephine Ryles, enslaved in Galveston, Texas, claimed to "hear some of 'em say somethin' bout jumpin' over de broom an' bein' married dat way, but it ain't true. No'm, dats jus' a story. I seen a lot of marriages, an' dey was married regular." ${ }^{54}$ Similarly, ex-slave Partheny Shaw stated that jumping the broomstick "was just a sayin', they didn't jump over nothin'." 55 These and similar passages might initially cast doubt upon the authenticity of the ceremony as a legitimate marriage ritual. But the number of ex-slaves that affirmatively spoke of this tradition far outnumbers the doubters, suggesting that the ritual should not be dismissed as something enslaved people did not take seriously.

Recollections from both white and black respondents reveal that broomstick ceremonies were diverse, ranging from those where the broomstick was 
simply one element of a larger celebration, to those where it encompassed the whole ceremony. One anonymous respondent richly described her mother's experiences in the South:

I have often heard her tell when the colored folks got married the man would lay the broom down on the floor with the bushy end to the north, then he would take the girl by the hand, then they step over the broom, then backward again. Then the girl picked up the broom, laying it down again with the bushy end to the south, then the girl took the man by the hand and they step over it and backward again, to keep evil away and bad spirits through their life. Mother said many a night she would steal down and watch when she heard some of the colored folks were going to get married. ${ }^{56}$

The respondent's racial identity was not disclosed, though her language suggests that her mother was either white or otherwise not directly affiliated with the enslaved community. This enslaved couple's calculated maneuvers safeguarded them from evil spirits, and the depiction of both partners assisting each other over the broom suggests they accepted one another's partnership upon entering domestic life. Significantly, the respondent's mother had to "steal down" to observe the ritual process, suggesting that this ceremony represented an intriguing cosmology that remained important for this community. The way such traditions were recollected by the elders largely determined how successive generations visualized their cultural heritage.

While some historians view memory as an impediment for trusting the WPA narratives, deciphering how some respondents used selective memory is a useful methodological tool for analyzing African Americans' conceptions of the broomstick ritual after the Civil War. One interview with two ex-slaves named John and Laney reveals a scenario in which the memory of slavery was muddled by competing interpretations of slave culture and whether white Americans should be privy to certain details of slave life. When they were asked about slave marriages Laney based her description upon the oral traditions of her family: "My mother said they used to make up a new broom and when the couple jumped over it, they was married." It is at this point that John, who the interviewer suggests was the older of the two and "evidently embarrassed" by Laney's revelation, interjected: "Laney, that was never confirmed. It was just hearsay, as far as you know, and I wouldn't tell things like that." ${ }^{57}$ John's concluding statement is quite revealing. Why would John demand Laney to not "tell things like that," when other former slaves had held no problems revealing the ceremony to their own interviewers?

One likely reason centralizes within John's motivation to downplay any suggestion that slaves participated in activities that might appear odd to the white interviewer. John was aware of a white American culture that associated 
slave customs with marks of inferiority, and revealing these rituals to outside observers was a haunting reminder of a period he preferred to let die with its victims. While John did not necessarily suggest that his plantation's system of slave labor was benign, he portrayed the social lives of the slaves through a lens that favorably compared to white civility, in which slaves learned "to read and write," attended church every Sunday, worked faithfully for the master, and looked upon marriage "as something very solemn." 58 Thus, in contrast to Laney's account, John described a setting in which enslaved people lived in circumstances more socially acceptable to a white audience. Despite these contradictions, however, other sources detail that jumping the broomstick survived among rural black and white communities through the late nineteenth to midtwentieth centuries, and would attain a large-scale revival through political and popular movements in the latter half of the twentieth century.

Some former slaves felt that jumping the broom was sufficient in spite of the post-1865 laws that suggested otherwise. In one example, George Leonard claimed black couples continued to jump the broom "long after freedom came." ${ }^{59}$ Leonard's testimony suggests that certain black Americans maintained an affinity for the custom, perhaps using the broomstick ceremony for practical purposes. The South's population remained largely rural in comparison to an increasingly industrialized North, causing many southerners to reside on the periphery of the political and legislative core. In the case of Annie Morgan, she and her husband still married by jumping over the broom in front of her entire community, because in those "days hit were too fer ter go git a preacher an most colored folks married dat way." ${ }^{~}$ Others believed their slave nuptials were sufficient and chose to forego any legal process until it served a practical purpose. Nearly fifty years after the Civil War ended, The Hartford Herald reported 103-year-old Timothy Griffin and 73-year-old Lucy Woody were finally wedded by a minister after having been "slaves on the same plantation in North Carolina before the war . . having [previously] entered into the connubial state by the old slave custom of jumping over a broomstick." ${ }^{61}$ It is likely that this couple only decided to legalize the union due to the stringency of legal inheritance; otherwise it would have been counterproductive to wait so long for legal validation. In order to ensure their posterity might inherit whatever value was left after one or both parents died, legalizing the union was a sensible maneuver in providing some financial assistance to future generations. Thus, while the legal circumstances of marriage changed for African Americans in the postbellum period, certain customs that originated in slavery still held resonant value.

It is at this point that African Americans' broomstick weddings intersect with their white contemporaries. Prior to the Civil War, enslaved people used the broomstick tradition due to the legal restrictions that characterized chattel slavery, but its continued use in the postbellum period reflects the social and cultural similarities that African Americans shared with poor, rural whites. While racial separation and oppression were intensely enforced through the establishment of Jim Crow legislation, black and white southerners shared cul- 
tural similarities rooted in both transnational and regional experiences. ${ }^{62}$ Those who continued to use the broomstick ceremony typically inhabited the most isolated regions. As late as the mid-twentieth century, the folk traditions of Missouri recounted that "in the absence of the clergy in pioneer days some method had to be found to unite those who desired wedlock ... having the young couple step over a broomstick was a sign of their devotion and their desire to be wedded." ${ }^{63}$ The usual stipulation for this approach was that the couple promised to get married by a minister at their first opportunity, but the broomstick wedding was a process in which the couple entered marital life through ceremonial commitment in the absence of clerical authority ${ }^{64}$

While this ceremony touched various portions of the rural United States, Kentucky was a favored location in postbellum literature for depicting broomstick weddings due to the isolation of the Appalachian Mountains, difficult roadways, and stereotypes of the inhabitants. ${ }^{65}$ For instance, in the $1880 \mathrm{~s}$ one politician's career was ruined when the press discovered "that his original marriage was a sort of 'broom-jumping' Kentucky affair of which there is no record." ${ }^{66}$ The designation of the "broom-jumping" as a "Kentucky affair" enhanced the stereotype of a population that was considered politically and culturally peripheral to an increasingly industrialized North America. Similarly, Eleanor Kelly's 1916 novel Kildares of Storm depicted a revealing conversation between a local Kentucky mountaineer and an inquisitive outsider named Channing. When Channing assumes that jumping over a broomstick was the common form of marriage in the mountains, the local peddler replies: "Well, stranger, a broomstick's better than nothin', I reckon ... It kinder stands fer law and order, anyway. I've knowed folks down around these parts, whar they's aplenty of preachers, to take up with each other 'thout'n so much as a broomstick to make things bindin'-like." ${ }^{\prime 67}$ In this instance, the nomadic respondent explains that certain couples decided to forego the minister's ceremony, despite the fact that it was available to them. In fact, the broomstick wedding attains a higher caliber in this rendition, since some couples did not even avail themselves of that ceremony. Outside of its pragmatic usage among Appalachian whites, the broomstick wedding appealed to populations who faced religious institutions that demanded doctrinal conformity. In opposition to a well-organized, morally conservative Catholic Church, evidence suggests that Louisiana Cajuns used the broomstick wedding as a way to derail certain ecclesiastical leaders.

Among Louisiana Cajuns the phrase "jumping (over) the broomstick" survived into the twentieth century and became a familiar colloquial expression that denoted a marriage not sanctioned by the Church. Cajuns who lived deep in the antebellum Louisiana bayous unfortunately did not leave a large documentary record for historians, but their postbellum folklore is particularly valuable in examining continuity in their cultural worldviews. Folklorist Carolyn Ramsay's 1950s excursions into multiple communities throughout the bayou found that the phrase sauter l'balai was still used frequently among Cajun men. Ramsay recorded that this practice of irregular marriage was used most fre- 
quently among isolated groups in the interior: "The people here "no like' the words the priest has to say over the couple; they prefer to sauter l'balai, the 'jump-the-broom-stick' method which was the way of their fathers . . . From the few outsiders that know these people, I learned later that their marriages stick. They don't jump the broomstick but once and family life is a very stable affair." ${ }^{\prime 68}$ Further description of the actual ceremony in this account suggests that no physical leap was required by the 1950s. Instead, the term became a colloquial expression that denoted the couple's rejection of marriage sanctioned by the church. Describing the courtship process of one couple named Jacques and Marianne, the process was a communal event that led up to a ceremony that simply required 'Marianne go to Jacques' home to live and den dey are married." ${ }^{\circ 9}$ It appears that this group of Cajuns utilized the concept of sauter l'balai as a rejection of clerical authority, but they simultaneously maintained that couples who used this tradition took marriage seriously. Interestingly, exslaves held similar sentiments. Callie Williams of Alabama claimed that despite her parent's humble ceremony under slavery, "they stuck lots closer then." 70 Both black and white rural southerners defended their traditions as suitable for their own community's needs, but frontier traditions were rapidly becoming minimized as more rural Americans flocked into cities in the twentieth century.

Despite the weakening of this rural practice through improved modes of transportation and the further colonization of the American frontier, folk speech and oral history kept jumping the broomstick alive in the memories of many descendant communities. The efforts of professional folklorists and the writers of the WPA in the 1930s were particularly important for documenting and preserving the traditions of rural Americans. In addition to their descriptions of slave weddings, folklorists recorded rhyme schemes that reminded descendant communities of how their ancestors married. One of the most vivid examples is found in the poem "Slave Marriage Ceremony Supplement" recorded in the 1920s, in which the couple is told: "De broomstick's jumped, de worl's not wide/She's now yo own. Salute yo' bride!"71 This passage reveals how twentieth-century African Americans employed traditional rhyming patterns to preserve an oral history that memorialized the broomstick wedding, even if they did not actually use the custom for their own nuptials.

Rural whites also used colloquialisms and music to preserve their traditions, as depicted in a popular 1959 rockabilly song by Brenda Lee, a native of Atlanta, Georgia, with titles "Let's Jump the Broomstick": "Goin' to Alabama back from Texarkana, Goin' all around the world/. . . My father don't like it, my brother don't like it, my sister don't like it, my mother don't like it/Come a little baby let's jump the broomstick, Come a let's tie the knot/." ${ }^{\prime 2}$ Lee's rendition of a broomstick wedding is likely employing a colloquialism that sprung from the literal practice. Jumping the broomstick was often used as a synonym for "irregular marriage," a form of matrimony where parties wed by mutual consent often outside ecclesiastical or parental support. This particular lyric suggests that the parties were motivated to marry despite the family's disapproval. Lee's 
use of the term "tie the knot" reveals that both phrases were equally known to designate a wedding, even if the couple did not literally jump over a broomstick or tie a knot. Thus, even if certain rural couples did not perform the literal broomstick wedding in the mid-twentieth century, memories of the tradition were maintained through folk speech.

The aforementioned evidence shows that the broomstick custom resonated in rural communities from the nineteenth century into the twentieth, but many authors cite the release of Roots in the 1970s as the catalyst for the custom's re-popularity in contemporary African American culture. ${ }^{73}$ While Haley's book was ostensibly produced through his dedicated years of research and capacity for imaginative storytelling, Roots' portrayal of slave culture was intertwined with scholarly debates that sought to recapture the history of slavery from the ideology of "the Lost Cause," that the Civil War was a war of "northern aggression" and its historical justifications that slavery served as a necessary civilizing force for African Americans. Prior to the 1970s, most popular works portrayed slaves as cultureless and docile laborers degraded by the experiences of slavery in the United States. ${ }^{74}$ Even more importantly, at least from the perspective of popular culture, was the notion of the loyal slave that Margaret Mitchell wrote into her 1936 fictional sensation Gone with the Wind and its subsequent feature film adaptation released in 1939. In contrast, Haley's account came in tandem with a newer scholarship on slavery within labor history in the mid-twentieth century. This literature demonstrated how slaves held a vibrant culture distinct from its Euro-American counterpart, and novelists actively unearthed these intricacies of slave culture and its relevance to the overall experience of black people in the United States. The term "jumping the broom," for instance, was used in Margaret Walker's 1960s work Jubilee. This novel operated as a historical fiction depicting the experiences of Walker's enslaved and free ancestors in the nineteenth century South. In one section of the work, the main character Vyry asks her master for permission to marry, to which he responds "Well, now that's no trouble, lots of gals are getting married around here every day, how do you say, 'jumping the broom?"'75 The phrase was used to denote the idea that slaves married in a fashion different from white people. Whether Walker intended this to mean a literal jump over the broomstick or a colloquial expression is difficult to discern from this passage, but employing the phrase $\mathrm{i}$ with African American slavery is important for understanding how black cultural identity in the mid-1960s was shifting popular conceptions of American slave heritage.

Both Jubilee and Roots were fictional works that imaginatively recreated each author's familial genealogy from slavery to freedom. In other pieces of African American literature in the 1960s, authors also used fiction to depict their ancestors' experiences. In 1968, The Negro Digest featured a short piece titled "The Black Woman's Soliloquy," in which the author employs a first-person perspective illustrating the experiences of African American women from slavery to freedom. After tracing the experiences of black women from Africa to the American South, the author describes a slave wedding: "I met a man, a slave 
like me, and according to the white Christian law of that time, I married him by jumping over a broomstick among our friends. I would have liked a preacher, but this was not to be allowed." ${ }^{\prime 6}$ This popular commemoration of slave heritage provided a format in which jumping the broom could regain its footing in African American consciousness.

The broomstick tradition's entrance into black popular culture, however, did not attain its full potential until it arrived at other venues. Ebony and Jet Magazine, two of the most popular African American publications, clearly delineate this shift in popular mentality. Until the 1970s, both magazines were silent on broomstick marriages. While images and descriptions of African American marriages in the late 1960s reveal the inclusion of Afrocentric elements, as couples dawned "traditional" garb and included West African symbols, it is not until the 1970s that one sees the phrase "jumping the broom" actually used in these publications. As early as February 1971, Lerone Bennett, Jr., social historian and Senior Editor of Ebony, briefly highlighted jumping the broom as a method of slave marriage in the US South. ${ }^{77}$ Bennett was regularly publishing articles in Ebony on black history since 1963, and these sections on broomstick weddings were extracted from his book Before the Mayflower: A History of Black America.$^{78}$ Though the book was released in 1962, Bennett felt compelled to disseminate his findings on slave marriages nearly one decade later to audiences who remained unfamiliar with his scholarly work.

The decision to publish extracts from Before the Mayflower in a popular magazine resonated with the magazine's readership, as one finds references to the broomstick wedding far more frequently in subsequent issues. In November 1971, Gerri Majors's "Society World" in Jet reported an "African-inspired wedding" that utilized the broomstick custom, suggesting that traditions stressing homage to ancestors through ritual symbolism were growing in African America. ${ }^{79}$ In 1975, the colloquial expression was used as the title of an article discussing marriage legislation. ${ }^{80}$ Bennett received much acclaim for his publication and submitted a second article called "The Roots of Black Love" in 1981 to combat stereotypes that highlighted the controversies surrounding the black family in America. Bennett highlighted the significance of the "proverbial broomstick" for enslaved people and proved that, despite their circumstances, African Americans held strong familial bonds whether free or enslaved ${ }^{81}$

This new literature scrutinizing the dynamics of US slave families helped develop Haley's story, but after Roots' was published, many scholars criticized his research methods, historical accuracy, and the ethics of his data collection. ${ }^{82}$ Haley would in fact experience three separate lawsuits following Roots' publication. One suit in particular dealt with accusations from Margaret Walker, who argued that Haley plagiarized sections of her work Jubilee. Walker's case revolved around Roots' allusions to slave customs, especially jumping the broom, which she argued Haley would not have known without reading her work. In her own words, "If Haley didn't read Jubilee, somebody read it—Maybe he didn't write Roots! Whoever wrote Roots . . copied Jubilee!"83 Throughout the 
trial Haley repeatedly defended his position, and the trial transcripts provide a useful source in unraveling the importance of slave folk customs to African American cultural memory in the 1970s.

In certain respects, the trial exposed the contested origins of the custom to a broader audience. In one report from The New York Amsterdam News, a black newspaper, the contributor reported that Margaret Walker unsuccessfully sued Haley by "claiming he stole portions of her book, Jubilee, especially the 'jump the broom' sections." ${ }^{84}$ The newspaper's focus upon the question of Haley's potential plagiarism of jumping the broom is fascinating, since it comprised only one of the many accusations that Walker leveled against him. To be sure, it was a significant component within the trial, and the prosecuting attorneys required Haley to explain the origins of his knowledge. Haley testified that his familiarity predated Walker's purported influence, explaining, "if we come to the expression 'jumpin' de broomstick,' it was common. I don't think there is any expression as prevalent. I can't even think of one that comes close, in the light of the idiomatic way slaves express the act of marriage. It was called 'jumpin' de broomstick." " ${ }^{85}$ Haley grounded his answer in southern folk speech, claiming his Tennessee upbringing made him aware of slavery's contribution to African American culture in the twentieth century. While it is difficult to conclusively determine if Haley was being entirely truthful, the aforementioned oral histories of both white and black communities validate his contention that jumping the broom was a familiar concept to those raised in the rural South.

Haley attributed his novel's success to the rich oral traditions of his childhood and his interviews with oral historians in the Gambia called griots, a group he described as "walking, living archives of oral history." ${ }^{86}$ But he maintained that his research methodology also went beyond oral history, as he consulted "antebellum memoirs, diaries, personal correspondence . . by slave masters and mistresses ... [and] the transcripts of several hundred interviews with completely unknown ex-slaves . . conducted by unemployed writers during the Thirties. ${ }^{187}$ Additionally, Haley acquired intellectual assistance from his scholarly associates. The trial transcripts reveal that he received help from various associates familiar with the WPA narratives and counted Lerone Bennett, Jr. as a confidant in his research. ${ }^{88}$ Bennett's support would have been critical in this regard, as his work previously argued that slaves performed multiple variations of this marital custom. In turn, Roots presented a more vivid description of the broomstick ceremony and ultimately eclipsed the colloquial reference used by Walker. While both authors surely grew up hearing their elders use the expression, it was Haley's attention to detail that positioned his portrayal of the ritual at the center of American consciousness.

In addition to the rich literary depiction, however, it is necessary to consider Roots' cultural impact through television. Roots achieved significant influence as a novel, but it was the eight-part television miniseries of the same name that cemented its position in popular culture. As geographer Paul Adams argues: "Culture and television are clearly involved in reciprocal relations: 
television affects culture, but culture also affects television in regard to interpretative strategies and social attitudes toward viewing." ${ }^{89}$ The Roots miniseries brought depictions of slaves' lives to the homes of individuals that, while interested in the African American experience, may not have had the time or ability to read the dense historical works that composed the foundation of his historical fiction. ${ }^{90}$ Disseminating these ideas beyond the written word secured the broomstick wedding's increased popularity in African American culture. After the miniseries aired on television, one sees increased attention to the broomstick wedding throughout the 1980s, and even more into the 1990s..$^{91}$ In one example, the impact of the miniseries is depicted in the personal journal of Danita Rountree Green, who became a popular wedding planner and coordinator in the 1990s. Green's October 1976 journal entry reveals how the miniseries resonated with young African Americans: "Roots was on again last night and I can't get anything done. Kunta and Bell got married and jumped the broom just like those old folks used to talk about. I thought they were joking." ${ }^{\prime 2}$ If Green's account is typical, it suggests that many African Americans grew up hearing stories of broomstick ceremonies, but it was Roots' depiction of the ritual that validated their family's oral history. The descendant community was now prepared to pay homage to their ancestors by reenacting a custom many believed was crucial to understanding slavery in American history.

Nearly four decades after Roots premiered on television African Americans continue to jump the broom, but evidence suggests that its practicality for the new generation has been challenged in recent media. The 2011 film Jumping the Broom is arguably the most potent revelation that the ritual continually maintains a position in the cultural identity of black America. Indeed, the film's title is a loud declaration for the custom's resonance in the twenty-first century. Jumping the Broom's plot is premised upon the clash of two socially distinct black families who, despite sharing the same racial identity, disagree on the utilization of symbols commemorating slave heritage in modern African America. For the young bride and groom, jumping the broomstick represented a slave past that black couples seeking a "modern" ceremony needed to discard, asserting that one's blackness in American culture is not just defined by slave ancestry or embracing popular expressions of black culture. The families are also divided economically, as the groom's blue-collar matriarch insists that jumping the broom is necessary to preserve one's heritage, while the bride's affluent mother mockingly reveals that her family "owned slaves" during a heated disagreement at a pre-wedding dinner. ${ }^{93}$ The movie tackles questions of black American identity in the twenty-first century, leading to the climactic moment when the couple must decide whether or not they will "jump the broom" at the altar.

In the end, the broomstick ceremony wins out. But the film's larger question asks how African Americans entering into an upper-middle- and upperclass society maintain a sense of "blackness" that is culturally distinct from elite Anglo society without alienating themselves from these same prosperous white circles. Thus, Jumping the Broom highlights the younger generation's 
opposition to the ritual as they hope to overcome the social ostracism associated with American segregation throughout the twentieth century. The young couple portrayed in the film saw the broomstick wedding as a relic of the past that, while useful for previous generations, provided little meaning for those seeking to thrive in American society, and not just survive. The movie displays the notion that as social class changes, racial consciousness is reconfigured, and certain archaic traditions are left by the wayside. The symbol of the broomstick in African American marriage lies at the core of this issue.

Due to increased mobility and communication technology, one could argue the broomstick wedding no longer serves its original purpose as a way for couples to pledge their commitment to one another in absence of clergy or justice of the peace. Since the cultural mainstream in the United States is based less in rural traditions, many younger Americans have disassociated themselves from ancestral folk customs in favor of modernized ceremonies like the popular "white wedding." ${ }^{94}$ In consequence, the African American community is one of the last groups invested in maintaining the tradition, but recent evidence suggests that this might soon be changing as well. As displayed in Jumping the Broom, the couple's hesitancy to include the custom in their "modern" wedding ceremony illustrates the possibility that the broomstick wedding is approaching a second casualty within African American memory and/or cultural practice. The film suggests that as young African Americans enter occupations that allow increased opportunities for social mobility, they more frequently associate with white elites who hold their own methods of cultural expression. Just as the broomstick wedding was rejected by many newly freed black people as a relic of a past they preferred to move beyond, younger African Americans appear to be echoing similar sentiments that favor breaking with tradition and conformity. While one could contend that contemporary African Americans jump the broomstick "to demonstrate the persistence and respect for tradition," neglecting to consider its larger dilemmas within popular culture and political consciousness is a serious omission. ${ }^{95}$ One wonders how much longer this tradition will appeal to younger African Americans seeking to establish a way of life that contrasts with the experiences of their ancestors.

Jumping over the broomstick has become so intertwined with the African American experience that it has led some to believe that "if you're not African American, there's a fairly good chance you have not heard of jumping the broom. ${ }^{96}$ Despite a pervasive and documented tradition of these weddings occurring in white communities from the nineteenth to early twentieth centuries, white Americans are, with a few exceptions, largely detached from the custom when reflecting upon their own cultural heritage. ${ }^{97}$ While the phrase "jump the broom" continues in certain rural white communities and neo-pagan groups, most Americans maintain familiarity with the custom through media sources that privilege, or at least spotlight, the African American experience. Popular television shows like Grey's Anatomy and The Game have reemphasized the broomstick tradition's resonance in African American consciousness, which in 
turn inspire white viewers to associate the custom with black Americans. ${ }^{98} \mathrm{Of}$ course this development is nothing new, as patterns of cultural consumption in American popular culture caused other interracial traditions to experience similar historical trajectories.

Country music, for instance, rooted in the folk sounds of both black and white rural Americans, is now largely marketed as a "white music" genre that highlights the links between social conservatism, patriotism, and the legacy of (white) rural America. ${ }^{99}$ Similarly, scholars have revisited the place of "soul food" in American culture, highlighting that it was a cooking method based more on issues of class than race. Impoverished white and black southerners ate similar foods largely disdained by elites. While white and black methods of cooking differed in the amounts of spice and sweeteners each group used, the transition from the culinary category of "southern cooking" to "soul food" emerged alongside the spread of black culture outside the rural South and into urban areas throughout the United States. The connection between blackness and soul food increased during the Black Power movement and gave the once "shared regional cuisine a racial edge that completely excluded Southern whites." 100 Thus, while many connect soul food with black cooking, southern cooks, both black and white, would likely call it "home cooking." Jumping the broom holds a similar history, in that it reveals how the interplay between memory and popular culture shapes Americans' interpretations of their cultural traditions through a racial paradigm. This is not to say that the historical experiences of various ethnic and racial groups in the United States have not crafted their own unique cultures, but jumping the broom's multicultural history should motivate scholars to continually reevaluate ideas and patterns deemed culturally exclusive to individual groups throughout American history.

\section{Notes}

The author would like to thank Daniel C. Littlefield, Robert Greene II, Bobby Donaldson, and Michael Woods for their assistance with this work. They would also like to recognize the helpful critiques provided by conference members at the 2010 South Carolina Historical Association conference and the 2012 annual conference of the British Group of Early American Historians. 1976), 310

1. Alex Haley, Roots: The Saga of An American Family (Garden City, NY: Doubleday,

2. Ibid., 325.

3. Ibid., 506 .

4. Alan Dundes, “'Jumping the Broom': On the Origin and Meaning of an African American Wedding Tradition," The Journal of American Folklore 109 (1996): 327; Elizabeth H. Pleck, Celebrating the Family: Ethnicity, Consumer Culture, and Family Rituals (Cambridge, MA: Harvard University Press, 2000), 230; Harriet Cole, Jumping the Broom: The African American Wedding Planner (New York: Henry Holt \& Company, 2004), 10-11; Cele C. Otnes and Elizabeth H. Pleck, Cinderella Dreams: The Allure of the Lavish Wedding (Berkeley: University of California Press, 2003), 248-249; Susan Safidi, Who Owns Culture?: Appropriation and Authenticity in American Law (Piscataway, NJ: Rutgers University Press, 2005), 38-39; Lorie Baptista, "Black Wedding Traditions," in Encyclopedia of African American History, eds. Leslie M. Alexander and Walter C. Rucker (Santa Barbara, CA: ABC-CLIO, 2010), 158.

5. Some publications maintain the belief that "jumping the broom" is solely an African American phenomenon: Mary Ann Lamanna and Agnes Riedmann, Marriages \& Families: Making Choices in a Diverse Society (Belmont, CA: Thomson Wadsworth, 2008), 172; "Weddings," 
Black Family Today, 1 (1995), 17-18. Some writers contend that white people using the broomstick wedding is a gross form of cultural appropriation: see Danielle Young, "White Couple Jumps the Broom, and We're Like, No You Can't Do That [updated]," Hello Beautiful, accessed August 7, 2015, http://hellobeautiful.com/2014/11/11/history-of-jumping-the-broom/.

6. For an explanation of "collective memory," see Maurice Halbwachs, On Collective Memory, trans. and ed. Lewis A. Coser (Chicago: University of Chicago Press, 1992).

7. Examples of works that briefly mention the custom are extensive, and the following references provide only a sample: Marion B. Lucas, A History of Blacks in Kentucky: From Slavery to Segregation, 1760-1891, vol. 1 (Frankfort, KY: Kentucky Historical Society, 1992), 19; Kelly Brown Douglas, Sexuality and the Black Church: A Womanist Perspective (Maryknoll, NY: Orbis Books, 1999), 66; Katherine M. Franke, "Becoming a Citizen: Reconstruction Era Regulation of African American Marriages," Yale Journal of Law and Humanities 11 (1999): 252, 272; Clayton E. Jewett and John O. Allen, Slavery in the South: A State-by-State History (Westport, CN: Greenwood Press, 2004), 72, 108. Even works specifically dedicated to enslaved marital relationships and family life do not go beyond a basic description of the activity: Bobby Frank Jones, "A Cultural Middle Passage: Slave Marriage and Family in the Ante-Bellum South" (PhD diss., University of North Carolina-Chapel Hill, 1965), 93-94; Ann Patton Malone, Sweet Chariot: Slave Family and Household Structure in Nineteenth-Century Louisiana (Chapel Hill: University of North Carolina Press, 1992), 224; Anthony S. Parent Jr. and Susan Brown Wallace, "Childhood and Sexual Identity Under Slavery," Journal of the History of Sexuality 3 (1993): 379-380; Larry Hudson, To Have and to Hold: Slave Work and Family Life in Antebellum South Carolina (Athens, GA: University of Georgia Press, 1997), 159; Orville Vernon Burton, In My Father's House Are Many Mansions: Family and Community in Edgefield, South Carolina (Chapel Hill: University of North Carolina Press, 1985), 150; Carl H. Moneyhon, "The Slave Family in Arkansas," The Arkansas Historical Quarterly 58 (1999): 31-32; Darlene C. Goring, "The History of Slave Marriage in the United States," The John Marshall Law Review 39 (2005-2006): 309-310.

8. Elizabeth Freeman, The Wedding Complex: Forms of Belonging in Modern American Culture (Durham: Duke University Press, 2002), 90; Leslie M. Alexander and Walter C. Rucker, eds., Encyclopedia of African American History, vol. 1 (Santa Barbara: ABC-CLIO, 2010), 158.

9. Earlier scholarship paid some attention to the custom due to its novelty and stressed its primacy in slave marital rituals, see Jones, "A Cultural Middle Passage," 93, 94; ed. George P. Rawick, The American Slave: A Composite Autobiography, vol. 1, From Sundown to Sunup: The Making of the Black Community (Westport, CT.: Greenwood Publishing Co., 1972), 86; Eugene Genovese, Roll, Jordan, Roll: The World the Slaves Made (New York: Random House, 1972), 480; Herbert Gutman, The Black Family in Slavery and Freedom 1750-1925 (New York: Vintage Books, 1976), 273-283; Charles Joyner, Shared Traditions: Southern History and Folk Culture (Urbana: University of Illinois Press, 1999), 52. In the forthcoming usage of the WPA slave narratives this article uses those found in the forty-volume collection edited by the George P. Rawick, whose collection is referenced above in this footnote, who separated the narratives into three different series.

10. Shane White and Graham J. White, Stylin': African American Expressive Culture from Its Beginnings to the Zoot Suit (Ithaca, NY: Cornell University Press, 1998), 32.

11. John Blassingame, The Slave Community: Plantation Life in the Antebellum South (1972; revised New York: Oxford University Press, 1979), 166.

12. Ibid., 167.

13. Herbert Gutman, The Black Family in Slavery and Freedom, 1750-1925 (New York: Vintage, 1977), 282.

14. Gutman, The Black Family, 277-278. Gutman spends numerous pages postulating the ritual's cosmological significance to the enslaved, comprising pages 276-284.

15. Claude H. Nolen, African American Southerners in Slavery, Civil War, and Reconstruction (Jefferson, NC: McFarland \& Company Publishers, 2001), 22, 40; Wilma A. Dunaway, The African American Family in Slavery and Emancipation (Cambridge, UK: Cambridge University Press, 2003), 117-118; Emily West, Chains of Love: Slave Couples in Antebellum South Carolina (Chicago: University of Illinois Press, 2004), 33; Tammy K. Byron, "“A Catechism for their Special Use': Slave Catechisms in the Antebellum South" (PhD Diss., University of Arkansas, 2008), 137; Diane Mutti Burke, On Slavery's Border: Missouri's Small-Slaveholding Households, 1815-1865 (Athens, GA: University of Georgia Press, 2010), 204; Daina Berry, "Swing the Sickle for the Harvest Is Ripe": Gender and Slavery in Antebellum Georgia (Urbana: University of Illinois Press, 2010), 58.

16. For scholars arguing the ritual was a largely meaningless gesture, see Blassingame, The Slave Community, 166-167; Marie Jenkins Schwartz, Born in Bondage: Growing Up Enslaved in the Antebellum South (Cambridge: Presidents and Fellows at Harvard College, 2001), 205. For those arguing it was a "forced" practice, see Dundes, "Jumping the Broom," 328; Brenda E. Stevenson, Life in Black and White: Family and Community in the Slave South (Oxford: Oxford University Press, 1996), 229; Patrick O’Neil, "Bosses and Broomsticks: Ritual and Authority in Antebellum Slave Weddings" Journal of Southern History 75 (2009): 29-48. For those who believe the ritual 
was an act of resistance, see Mark Anthony Neal, "Jumping the Broom to Equality," Huffington Post Blog, Updated October 8, 2011, http://www.huffingtonpost.com/mark-anthony-neal/newyork-gay-marriage b 913653.html; Lamanna, Riedmann, and Strahm. Marriages, Families, and Relationships, 183. Other scholars are a bit more divided on the question: Thomas E. Will, "Weddings on Contested Grounds: Slave Marriage in the Antebellum South," The Historian (1999): 117. For a review of the literature and a conclusion concerning how the ritual is a product of cultural exchange, see Tyler D. Parry, "Married in Slavery Time: Jumping the Broom in Atlantic Perspective," Journal of Southern History, 81 no. 2 (May 2015): 273-312.

17. One unpublished dissertation pays some attention to this question, though discussions of the broomstick wedding are spread throughout the work's larger interest in the evolution of Louisiana plantation weddings. Cherry Lynne Pyburn Levin, "Wedding Belles and Enslaved Brides: Louisiana Plantation Weddings in Fact, Fiction and Folklore" (PhD Diss., Louisiana State University, 2012), 159-176, 343, 350-351.

18. Martha Griffith Browne, Autobiography of a Female Slave (New York: Redfield, 1857), 211.

19. The American Slave, vol. 6, supplement, series 1, Mississippi Narratives, 262-263; The American Slave, vol. 3, supplement, series 1, Georgia Narratives, 332; The American Slave, vol. 3, supplement, series 1, Georgia Narratives, part 1, 64. Other respondents simply stated that weddings were times of feasting and merriment, and omitted any reference to preachers or Christian ceremony. For examples of this diversity, see The American Slave, vol. 3, supplement series 1, Alabama Narratives, 114; The American Slave, vol. 7, supplement, series 1, Mississippi Narratives, 696-697; The American Slave, vol. 8, supplement, series 1, Mississippi Narratives, 1080; The American Slave, vol. 5, supplement, series 2, Texas Narratives, 1566; The American Slave, vol. 6, supplement, series 2, Texas Narratives, 2197.

20. C. Vann Woodward, "History From Slave Sources," American Historical Review 79 (1974): 470-448; John W. Blassingame, "Using the Testimony of Ex-Slaves: Approaches and Problems", Journal of Southern History 41 (November 1975): 473-492; Thomas F. Soapes, "The Federal Writers' Project Slave Interviews: Useful Data or Misleading Source," Oral History Review 2 (1977): 33-38; David Thomas Bailey, "A Divided Prism: Two Sources of Black Testimony on Slavery." Journal of Southern History 46 (August 1980): 381-404; Norman R. Yeatman, "Ex-Slave Interviews and the Historiography of Slavery," American Quarterly 36 (Summer, 1984), 181-210; Paul D. Escott, "The Art and Science of Reading WPA Slave Narratives," in The Slave's Narrative, eds. Charles T. Davis and Henry Louis Gates Jr. (Oxford: Oxford University Press, 1985); Herbert C. Covey and Paul T. Lockman Jr., "Narrative References to Older African Americans Living under Slavery," Social Science Journal 33 (1996): 23-37; Donna J. Spindel, “Assessing Memory: Twentieth-Century Slave Narratives Reconsidered," Journal of Interdisciplinary History 27 (Autumn 1996): 247-261; Sharon Ann Musher, "Contesting 'The Way the Almighty Wants It': Crafting Memories of Ex-Slaves in the Slave Narrative Collection," American Quarterly 53 (2001): 1-31; John D. Fair, "The Georgia Slave Narratives: A Historical Conundrum," The Journal of the Historical Society 10 (2010): 235-281.

21. Blassingame, The Slave Community, 167. For scholars who followed Blassingame's argument, see Wilma King, Stolen Childhood: Slave Youth in Nineteenth-Century America (Bloomington, IN: Indiana University Press, 1995), 63; Anthony Kaye, Joining Places: Slave Neighborhoods in the Old South (Chapel Hill: University of North Carolina Press, 2007), 253, n.81.

22. To demonstrate this I have at least one reference from an ex-slave that lived in a state either from the former confederacy or the slave-holding border states. It is important to keep in mind that ex-slaves did not always live in the same state in which they were interviewed, which explains why certain collections have multiple references. The following sample provides a wide selection of different people testifying to broomstick ceremonies that took place throughout the South: The American Slave, vol. 2, South Carolina Narratives, part 1, 323; The American Slave, vol. 4, Texas Narratives, part 1, 45-46, 158, 206-207, 293; The American Slave, vol. 5, Texas Narratives, part 3, 64; The American Slave, vol. 7, Oklahoma Narratives, part 1, 32, 295; The American Slave, vol. 7, Mississippi Narratives, part 2, 87; The American Slave, vol. 8, Arkansas Narratives, part 1, 75; The American Slave, vol. 10, Arkansas Narratives, part 5, 329-330; The American Slave, vol. 12, Georgia Narratives, part 1, 101; The American Slave, vol. 16, Maryland Narratives, part 3, 7; The American Slave, vol. 18, Unwritten History of Slavery, 174.

23. Its impact among white communities is examined later in the article, but for the reader's perusal this footnote provides a few accounts outside the WPA narratives that reference the broomstick wedding: Annie L. Burton, Memories of Childhood's Slavery Days (Boston: Ross Publishing Company, 1909), 5; William H. Robinson, From Log Cabin to the Pulpit, or Fifteen Years in Slavery (Eau Claire, WI.: James H. Tifft, 1913), 152; Miles M. Fisher, The Master's Slave: Elijah John Fisher, A Biography (Philadelphia: The Judson Press, 1922), 5; William Wells Brown, The Escape; or, A Leap for Freedom. A Drama in Five Acts (Knoxville,: University of Tennessee Press, 2001), 26. Brown largely replicated this reference in one of his postbellum publications: see William Wells Brown, My Southern Home: or, The South and Its People (Boston: A.G. Brown \& Company, 1880), 42-46. Additionally, while "WPA narratives" is a convenient umbrella term for many of the narratives collected in the early twentieth century, not all of the materials I use can ap- 
propriately be deemed as such. Indeed, the WPA grew out of preceding efforts among black, and to a lesser extent white, folklorists and activists to collect the remaining testimonials of former slaves who were still alive in the early twentieth century. In an effort to employ out-of-work writers during the Great Depression, the federal government promoted the WPA initiative as a dual measure that provided employment to a section of the American population, while simultaneously preserving and documenting the traditions and oral histories of rural America. For discussions of these initiatives and studies that used materials similar to the WPA narratives, see George P. Rawick, ed., The American Slave, vol. 1, From Sundown to Sunup; George P. Rawick, ed., The American Slave, vol. 1, supplement, series 1, Alabama Narratives, General Introduction; Charles L. Perdue Jr., Thomas E. Barden, and Robert K. Phillips, eds., Weevils in the Wheat: Interviews with Virginia Ex-Slaves (Charlottesville: University Press of Virginia, 1976), Introduction; Ronnie W. Clayton, Mother Wit: The Ex-Slave Narratives of the Louisiana Writer's Project (New York: Peter Lang, 1990), 1-12; John B. Cade, "Out of the Mouths of Ex-Slaves," The Journal of Negro History 20 (July 1935), 294-337. For an examination of these sources as they related to the Great Depression, see Ronnie W. Clayton, “A History of the Federal Writers' Project in Louisiana” (PhD diss., Louisiana State University, 1974), 1-28.

24. Shane and Graham White first suggested that the ubiquity of jumping the broom had been exaggerated in past scholarship, but did not demonstrate any quantitative data to prove their contention; see White and White, Stylin', 32.

25. Harriet Cole, Jumping the Broom: The African American Wedding Planner (New York: Henry Holt and Company, 1993), 18; Danita Rountree Green, Broom Jumping: A Celebration of Love. A Complete Guide to Keeping Traditions Alive in Your Family (Richmond, VA: Entertaining Ideas Ltd., 1992), 3; Tolagbe M. Ogunleye, The African Roots of Jumping the Broom (Philadelphia: Cowrie Publishing Co., 2004).

26. In my own research on marriage rituals in West and West Central Africa during the transatlantic slave trade (1444-1888), I found no ceremonies that either featured brooms, or any in which brooms were jumped: see Tyler D. Parry, "Love and Marriage: Domestic Relations and Matrimonial Strategies among the Enslaved in the Atlantic World" (PhD diss., University of South Carolina, 2014), Chapter 1.

27. W. Rhys Jones, “'Besom Wedding' in the Ceiriog Valley,” Folklore 39 (June, 1928): 154 155. Also see T. Gwynn Jones, Welsh Folklore and Folk-Custom (1930; New Jersey: Rowman and Littlefield, 1979), 185.

28. George Paston, Social Caricature in the Eighteenth Century (1905; New York: Benjamin Blom, 1968), 29.

29. M. Eileen Lyster, "Marriage over the Broomstick," Journal of the Gypsy Lore Society 5 (1911-1912): 200-201.

30. Lyster, "Marriage over the Broomstick," 199.

31. V. S. Moorwood, Our Gypsies in City, Tent, and Van (London: Williams Clowes and Sons, Ltd., 1885), 141-142.

32. This builds upon a compelling argument made by Mechal Sobel, who used eighteenthcentury Virginia as a case study to argue that the culture of the U.S. South was crafted through interactions between lower-class whites and slaves. Mechal Sobel, The World They Made Together: Black and White Values in Eighteenth-Century Virginia (Princeton: Princeton University Press, 1988).

33. There do exist references to immigrants in the Northeast using a similar ceremony, but they are predominantly found in the twentieth century: see Edwin Miller Fogel, Beliefs and Superstitions among the Pennsylvania Germans (Philadelphia: American Germanica Press, 1918), 72. Additionally, Herbert Gutman located practices reported in northeastern newspapers, but his footnotes are particularly difficult to follow in this section: see Gutman, The Black Family, 277, 597.

34. Slave narratives reveal that brooms were used rather extensively upon the plantation, which suggests the practicality of using it as a primary instrument for the wedding: see The American Slave, vol. 6, supplement, series 1, Mississippi Narratives, part 1, 242; The American Slave, vol. 7, supplement, series 1, Mississippi Narratives, part 2, 645.

35. Parry, "Married in Slavery Time."

36. The American Slave, vol. 9, supplement, series 1, Mississippi Narratives, 1424.

37. The American Slave, vol. 12, Georgia Narratives, part 1, 307.

38. Brenda E. Stevenson, Life in Black and White: Family and Community in the Slave South (Oxford: Oxford University Press, 1996), 229; Patrick W. O’Neil, “Tying the Knots: The Nationalization of Wedding Rituals in Antebellum America" (PhD diss., University of North CarolinaChapel Hill, 2009), 186-231; O’Neil, "Bosses and Broomsticks," 29-48.

39. O’Neil, "Bosses and Broomsticks," 42-44.

40. The idea of ritual autonomy was argued in Schwartz, Born in Bondage, 204. In slight contrast, however, I suggest that masters were usually more interested in the marital rites of domestic slaves and other servants with whom they were closely affiliated. This information is displayed in Parry, "Married in Slavery Time." For literature on reproduction and slave breeding, see Gregory D. Smithers, Slave Breeding: Sex, Violence, and Memory in African American History (Gainesville: 
University Press of Florida, 2012); Pamela D. Bridgewater, Breeding a Nation: Reproductive Slavery, The Thirteenth Amendment, and the Pursuit of Freedom (Cambridge, MA: South End Press, 2008); Gerald S. Norde, "From Genesis to Phoenix: The Breeding of Slaves During the Domestic Slave Era, 1807-1863 and its Consequences” (PhD diss., University of Delaware, 1985).

41. Folklorist C.W. Sullivan was the first to propose the linkage between the cultural practices of Welsh immigrants with American slaves: C. W. Sullivan III, "Jumping the Broom': A Further Consideration of the Origins of an African American Wedding Custom," The Journal of American Folklore 110 (Spring 1997), 203-204; C. W. Sullivan, III, “Jumping the Broom': Possible Welsh Origins of an African-American Custom," Southern Folklore 55 (1998), 15-23. Subsequent analyses built upon this proposition and established some key documents that suggest cultural exchange occurred as early as the eighteenth century: Tyler D. Parry, "An Irregular Union: Exploring the Welsh Connection to a Popular African-American Wedding Ritual," in Welsh Mythology and Folklore in Popular Culture: Essays on Adaptations in Literature, Film, Television, and Digital Media, eds. Audrey L. Becker and Kristin Noone (Jefferson, NC: McFarland Press, 2011), 108-129.

42. The American Slave, vol. 1, supplement, series 1, Alabama Narratives, 424.

43. "Gathered News Fragments" Maine Farmer, April 21, 1853, 21, 17.

44. James Fenimore Cooper, The Prairie: A Tale (1827; revised and corrected, London: Richard Bentley, 1836), 339.

45. The American Slave, vol. 14, North Carolina Narratives, part 1, 185.

46. Past scholarship has shown the interactions that took place between poor whites and blacks in the antebellum period: Lawrence T. McDonnell, "Money Knows No Master: Market Relations and the American Slave Community," in Developing Dixie: Modernization in a Traditional Society, eds. Winfred B. Moore, Joseph F. Tripp, and Lyon G. Tyler (Westport, CN: Greenwood Press, 1988), 31-44; Jeff Forret, Race Relations at the Margins: Slaves and Poor Whites in the Antebellum Countryside (Baton Rouge: Louisiana State University Press, 2006).

47. Pop Goes the Weasel Songster (1853; Philadelphia: Fisher and Brother, 1938), 12-13. For literature discussing antebellum minstrelsy in greater detail, see Robert C. Toll, Blacking Up: The Minstrel Show in Nineteenth-Century America (Oxford: Oxford University Press, 1977), 93; Harry Birdoff, The World's Greatest Hit: Uncle Tom's Cabin (New York: S. F. Vanni, 1947); R. C. Toll, "From Folktype to Stereotype: Images of Slaves in Antebellum Minstrelsy," Journal of the Folklore Institute 8 (1971): 41.

48. "Divorces in Kentucky," New York Evangelist, March 9, 1848, 39.

49. "Circular No. 5: Rules and Regulations for Assistant Commissioners," The Freedmen's Journal 1 (1865): 131.

50. See Douglas Blackmon, Slavery by Another Name: The Re-Enslavement of Black People in America from the Civil War to World War II (New York: Doubleday, 2008), 13-38.

51. In one 1907 account a Richmond minister consented to perform the marriage ceremony for one black couple, "knowing what prestige would come to the couple by reason of having been married by a white minister": "Just as he was," Harper's Weekly, August 17, 1907, 1211.

52. The testimony of Bongy Jackson was quoted in Lyle Saxon, Edward Dreyer, and Robert Tallant, eds., Gumbo Ya-Ya: A Collection of Louisiana Folk Tales (Boston: Houghton Mifflin Company, 1945), 239.

53. The American Slave, vol. 15, North Carolina Narratives, 195.

54. The American Slave, supplement, series 2, vol. 9, Texas Narratives, part 8, 3406.

55. The American Slave, supplement, series 1, vol. 4, Georgia Narratives, part 2, 548; also see The American Slave, supplement, series 2, vol. 6, Texas Narratives, part 5, 2007; The American Slave, vol. 9, Arkansas Narratives, part 4, 26.

56. Harry Middleton Hyatt, Folklore from Adams County, Illinois, 2nd ed. (New York: Alma Egan Hyatt Foundation, 1965): 465.

57. The American Slave, vol. 13, Georgia Narratives, part 4, 84-85.

58. The American Slave, vol. 13, Georgia Narratives, part 4, first quote 78, second quote 84. By the standards of the WPA narratives, this is a lengthy interview that features both the voices of the formerly enslaved as well as the interviewer's commentary. For the full interview see pages 72-96 in the cited volume. Laney appears in the interview around page 82, and the interviewer notes that points where Laney interjects her own opinions, oftentimes doing so while John is still speaking.

59. The American Slave, vol. 13, Georgia Narratives, part 4, 268. Also see The American Slave, vol. 13, Georgia Narratives, part 4, 216.

60. The American Slave, vol. 16, Kentucky Narratives, 104.

61. "Parents May Object Due to Lucy's Youth," The Hartford Herald, September 4, 1912, 6. Another couple with nearly identical names were also reported to have been married at the same time. It is likely that this is the same couple: see "Negro Married Same Woman Nearly Fifty Eight Years Ago," The Bisbee Daily Review, September 3, 1912, 1.

62. For a broader examination of this concept, see John A. Burrison, Roots of a Region: Southern Folk Culture (Jackson, MS: University Press of Mississippi, 2007). 1951), 5 .

63. Earl A. Collins, Legends and Lore of Missouri (San Antonio, TX: The Naylor Company, 
64. Caroline Ann "Meta” Morris Grimball, Journal of Meta Morris Grimball: South Carolina, December 1860-February 1866, p. 95, available at docsouth.unc.edu. Also see Elizabeth Brandon, "Les Moeurs de la Paroisse de Vermilion en Louisiane" (PhD Diss., Laval University, 1955), 154; Elizabeth Brandon, "The Socio-Cultural Traits of the French Folksong in Louisiana," Revue de Louisiane, Louisiana Review 1 (1972): 30.

65. The reference is often found in Kentucky folk speech, but the expression is found throughout the United States as well. For Kentucky references see Kentucky Alumnus, vol. 7, October, 1915: 45; Jesse Stuart, "Jumping the Broom: Love in the Mountains." Collier's (January 1, 1938): 26-28, 44; James Nathan Tidwell, "Comments on Word-Lists in PADS," Publication of the American Dialect Society 13 (1950): 16.

66. "The Republican Saint's Broom-Jumping Kentucky Marriage," The Gazette Fort Worth Texas, September 30, 1884, 2.

67. Eleanor Mercein Kelly, Kildares of Storm (New York: The Century Company, 1916), 213.

68. Carolyn Ramsey, Cajuns on the Bayous (New York: Hastings House Publishers, 1957), 52.

69. Ramsey, Cajuns, 52.

70. The American Slave, vol. 6, Alabama Narratives, 428; for similar references see The American Slave, vol. 12, Georgia Narratives, part 2, 69; The American Slave, vol. 13, Georgia Narratives, part 4, 22; The American Slave, supplement, series 2, vol. 6, Texas Narratives, part 5, 2023; The American Slave, supplement, series 2, vol. 8, Texas Narratives, part 7, 3209.

71. Charles K. Wolfe, ed., Thomas W. Talley's Negro Folk Rhymes, rev ed. (1922; Knoxville: The University of Tennessee Press, 1991), 123.

72. While Lee's song was popular in the United States, "Let's Jump the Broomstick" reached number twelve in the UK charts, making its impact in Britain more potent than within the United States. For information on this song and her career, see Brenda Lee and Robert K. Oermann, Little Miss Dynamite: The Life and Times of Brenda Lee (New York: Hyperion Books, 2002), 37, 75, 164, 173, 246, 288.

73. Green, Broom Jumping; Cole, Jumping the Broom, 10; Otnes and Pleck, Cinderella Dreams, 248; Nathan Jackson, "Reclaiming Roots: Black Americans 'Jump the Broom' in African Inspired Weddings," Boca Raton News, November 14, 1993, 4E; Ramona Faith Oswald, Lesbian Rites: Symbolic Acts and the Power of Community (New York: Harrington Park Press, 2003), 62.

74. Ulrich Bonnell Philips, American Negro Slavery: A Survey of the Supply, Employment and Control of Negro Labor as Determined by the Plantation Regime (New York: D. Appleton and Co., 1918); Kenneth M. Stampp, The Peculiar Institution: Slavery in the Ante-Bellum South (New York: Alfred A. Knopf Inc., 1956); Stanley Elkins, Slavery: A Problem in American Institutional and Intellectual Life (Chicago: The University of Chicago Press, 1959).

75. Margaret Walker, Jubilee (Cambridge: The Riverside Press, 1966), 143.

76. Mignon Holland, "A Black Woman's Soliloquy: In the Face of Fire I will Not Turn Back," Negro Digest 17 (1968): 22. Five years later (a few years before Haley's publication), the magazine again featured an article describing the broomstick wedding: Kathryn Morgan, "On Black Image and Blackness," Black World/Negro Digest 23 (1973): 26.

77. Lerone Bennett Jr., "The World of the Slave," Ebony 26, no. 4 (February, 1971): 52.

78. Lerone Bennett Jr., Before the Mayflower: A History of Black America, 1619-1962 (New York: Johnson Publishing Company, 1962).

79. Gerri Majors, “Society World: Cocktail Chitchat,” Jet, November 11, 1971, 39.

80. "Weekly Almanac," Jet, May 22, 1975, 46.

81. Lerone Bennett Jr., "The Roots of Black Love: New Research Underscores Strong Bonds of Black Concern," Ebony 36, no. 10 (August, 1981): 31-37, esp. 34; reprinted under different titles in February 1996 and June 2003. Criticisms of the black family in slavery and freedom had a long historiographical tradition. For some of the more noteworthy works, see E. Franklin Frazier, The Negro Family in the United States (Chicago: University of Chicago Press, 1940); Kenneth Stampp, The Peculiar Institution: Slavery in the Antebellum South (New York: Vintage Books, 1956); Elkins, Slavery; Daniel P. Moynihan, The Negro Family, the Case for National Action (Washington, DC: Department of Labor, 1965).

82. Many of these criticism are found in a single review published almost directly after Roots' release: see Mark Ottaway, "Tangled Roots," The Sunday Times, April 10, 1977; also see Harold Courlander, "Kunta Kinte's Struggle to be African,” Phylon 47 (1986): 294; Charles T. Morrissey, "Oral History and the Boundaries of Fiction," The Public Historian 17 (1985): 41-42; Donald R. Wright, "Uprooting Kunta Kinte: On the Perils of Relying on Encyclopedic Informants," History in Africa 8 (1981): 208; Philip Nobile, "Uncovering Roots," The Village Voice, February 17, 1993.

83. Margaret Walker's Journal, May 6th, 1977, Journal 101. Margaret Walker Personal Papers, Digital Archives Project at Jackson State University. Digitized photocopies of Walker's journal available at http://margaretwalker.jsums.edu.

84. "Alex Haley Posthumously Beheaded in the Village Voice," The New York Amsterdam News, February 27, 1993, 28.

85. "December 16, 1977," Walker vs. Haley Trial Transcript, Box 48, Folder 6. Alex Haley Papers, University of Tennessee at Knoxville. Hereafter UT-K. 
86. Alex Haley, "Black History, Oral History, and Genealogy," The Oral History Review 1 (1973): 12 .

87. "Playboy Interview: Alex Haley," Playboy, January 1977, 75-78.

88. In addition to consulting Bennett's publications on slave culture, Haley divulged he "talked with Mr. Bennett before he had even written some of the things which he has written now because he and I have known each other and have long shared this mutual interest." Quote in the "December 13, 1977," Walker vs. Haley Trial Transcript, Box 48, Folder 4, Alex Haley Papers, UT-K.

89. Paul C. Adams, "Television as a Gathering Place," Annals of the Association of American Geographers 82 (March, 1992): 119. Sociologists in the 1980s took a great interest in the impact of television on American life and culture. For other studies on the influence on television during this pivotal moment in American history, see F. Scott Christopher, Richard A Fabes, and Patricia M. Wilson, "Family Television Viewing: Implications for Family Life Education," Family Relations 38 (1989): 210-214; Donna J. Hess and Geoffrey W. Grant, "Prime-Time Television and Gender-Role Behavior," Teaching Sociology 10 (1983): 371-388; Enid Gruber and Helaine Thau, "Sexually Related Content on Television and Adolescents of Color: Media Theory, Physiological Development, and Psychological Impact," The Journal of Negro Education 72 (2003): 438-456.

90. John E. Wills Jr., "Taking Historical Novels Seriously," The Public Historian 6 (1984): 42.

91. References to broomstick weddings became increasingly visible in Ebony and Jet during the 1980s and 1990s. See the following references: "Latest Trends in Tying the Knot," Ebony 43, no. 8 (June 1988), 31-34; Muriel L. Whetstone, "What the Bride of the "90s Wants in Her Big Day, Her Man and Her Love Life," Ebony 52, no. 8 (June 1997), 58-60, 138; Joy Bennett Kinnon, "Wedding Gowns," Ebony 53, no. 8 (June, 1998), 85-98; Gerri Majors, "Society World "African-Inspired Nuptials," "Jet (May 1, 1995), 29; Gerri Majors, "Society World: Afrocentric Ceremony," Jet (May 10, 1999), 28.

92. Danita Rountree Green, Broom Jumping: A Celebration of Love. A Complete Guide to Keeping Traditions Alive in Your Family (Richmond, VA: Entertaining Ideas, Ltd., 1992), 29.

93. For film reviews that delve into the aforementioned issues, see Roger Ebert, "Review: Jumping the Broom," May 4, 2011, http://rogerebert.suntimes.com/apps/pbcs.dll/ article?AID=/20110504/REVIEWS/110509996, accessed November 12, 2012; Stephanie Merry, "Mother-in-Law Joke Gone Wild," Washington Post, May 6, 2011; A. O. Scott, "Jumping the Broom (2011) 2 Families Put Asunder Just Before the "I Dos," "The New York Times, May 5, 2011; Marshall Fine, "HuffPost Review: Jumping the Broom," updated July 3, 2011, http://www.huffingtonpost.com/marshall-fine/huffpost-review-ijumping_b_856785.html.

94. For further information on the advent of the white wedding, see Chrys Ingraham, White Weddings: Romancing Heterosexuality in Popular Culture, 2nd ed. (Abingdon, UK: Routledge, 2008).

95. Frances Smith Foster, 'Til Death or Distance Do Us Part: Love and Marriage in African America (Oxford: Oxford University Press, 2010), 93.

96. Lamanna, Riedmann, and Strahm, Marriages, Families, and Relationships, 183.

97. The exceptions to this rule are those who affiliate with neo-pagan communities in both Britain and the United States who employ the custom in homage to a pre-Christian Celtic ancestry: see Gerina Dunwich, Wicca Craft: The Modern Witches Book of Herbs, Magick and Dreams (New York: Citadel Press, 1991): 59-60; Sally Griffyn, Wiccan Wisdomkeepers: Modern-day Witches Speak on Environmentalism, Feminism, Motherhood, Wiccan Lore, and More (Boston: Red Wheel LLC, 2002): 17; Gerina Dunwich, Witch's Halloween: A Complete Guide to the Magick, Incantations, Recipes, Spells, and Lore (Avon: The Provenance Press, 2007): 155.

98. In Season 9, Episode 10, of Grey's Anatomy, two African American doctors are shown jumping over a broom as an appendage to their wedding. While the show does not comment upon the meaning of the custom, its visual display is a definitive statement of how the show's creator, Shonda Rhimes, an African American woman, wanted to display the ceremony's important cultural symbolism. In Season 7, Episode 9, of The Game, Kelly, a white woman, and Chardonnay, a black woman, discuss Chardonnay's upcoming wedding to her fiancé Jason, also an African American. When Chardonnay reveals to Kelly her and Jason are jumping the broom, Kelly responds with condescension and sarcasm at the idea.

99. The notion of country as "white music" is prevalent among a number of black Americans, and certain scholars have now begun to investigate this historical process: see Les Back and Vron Ware, Out of Whiteness: Color, Politics, and Culture (Chicago: University of Chicago Press, 2002), esp. Chapter 8; Cynthia Yeldell, "Modern Sounds in Country \& Western," The Crisis (NovemberDecember 2007), 38; Ann Malone, "Charley Pride," in Stars of Country Music: Uncle Dave Macon to Johnny Rodriguez, eds. Bill C. Malone and Judith McCulloh (Urbana, IL.: Board of Trustees of the University of Illinois, 1975), 340-356.

100. Quote is taken from a 2013 interview with food historian Adrian Miller regarding his new book on soul food: see http://www.uncpress.unc.edu/browse/author interview?title id=3440, accessed June 6, 2014. For Miller's book see Adrian Miller, Soul Food: The Surprising Story of an American Cuisine, One Plate at a Time (Chapel Hill: University of North Carolina Press, 2013). 